\title{
THE JUNE UPRISING OF 1941
}

\section{VALENTINAS BRANDIŠAUSKAS \\ Genocide and Resistance Research Centre of Lithuania, Vilnius}

\section{Introduction}

The expansionist aims of two totalitarian powers - the Soviet Union and Nazi Germany - were achieved at the juncture of the ' 30 s and ' 40 s. Along with other Central East European countries, Lithuania, too, found itself the focus of expansion. In the summer of 1940, Soviet aggression put an end to Lithuania's sovereignty, while her geographical situation turned the occupation into longlasting reality.

The occupation and annexation of Lithuania in 1940 gave rise to resistance. The first to register their protest were Lithuanian ambassadors in different countries of the world. The violation of international law, and the breach of democratic principles in the election of the supreme legislative organ - the Seimas - usurping a nation's rights and political power - was the main object of their protest. The USSR's unprovoked aggression and the illegal incorporation of Lithuania into the Soviet Union were emphasized constantly. Although Lithuania did disappear de facto from the political map of Europe, its annexation was never recognised de jure by most Western powers.

Lithuania's liberation movement was joined by Lithuanian Americans and the Council to Aid Lithuania was set up in the USA. The most energetic movement for Lithuania's liberation was launched in Europe. That was conditioned by geographical proximity and the active position of former diplomats and a number of politically-minded refugees from Lithuania.

In September 1940 the Lithuanian National Committee was established in Rome, and it practically gained the role of government-in-exile. The Committee, however, did not become an effective operative organization for several reasons: the members of the Committee lived and worked in different countries - Ernestas Galvanauskas and Kazys Škirpa in Germany, Stasys Lozoraitis in Italy, Edvardas Turauskas in Switzerland, 
and they rarely left those countries. Neither were their political viewpoints unanimous: Škirpa's pro-German disposition was quite evident, and Lozoraitis and Turauskas were more of AngloAmerican orientation.

In November 1940 the Lithuanian Activist Front (hereafter LAF) was established in Berlin on the initiative of Škirpa, a former Lithuanian ambassador to Germany, with the aim of rallying the nation against the Soviet invasion. The LAF united people of various political views, since the desire to restore the independence of Lithuania was stronger than any ideological differences. In their official documents, The LAF was presented as a united organization, turning a blind eye to political or group interests, trying to find a modus vivendi between private ownership and state rights. Priority was given to national and public interests. Nevertheless, the organization's proclamations and manifestos were not entirely devoid of some declaration of the principles of national socialism - the personality cult of the leader, "national socialism', the elimination of the Jews from the political and economic life of the country, etc.

The leaders of the movement linked the success of their plans with Germany's expansion in the East and believed in its liberating mission. Therefore Škirpa probed into German attitudes towards the aims of the LAF, maintained close relations with the German Ministry of Foreign Affairs and with highranking officials of the German High Command, informing them about the objectives and activities of his organization.

The occupation and annexation of Lithuania could not but arouse resistance within the country itself. This sprang up spontaneously and branched out into various forms, involving different layers of society. Passive resistance soon gained momentum, i.e., boycotting any Soviet political activity. Proclamations and underground newspapers spread on a large scale.

It is rather problematic to speak about organized resistance, and an accurate evaluation is almost impossible owing to the fragmentary and often contradictory nature of surviving archival evidence. Nevertheless, it could be said with conviction that the most significant underground organization was set up in the 29th territorial riflemen corps of the Red Army (the corps was formed on the basis of the Lithuanian army). The organization was led by Major Vytautas Bulvičius. Regrettably, this organization was discovered, and its leaders were sentenced to death. 
Lithuanian underground activists kept in touch with the LAF in Berlin. Its headquarters, undertaking the role of the central institution, aimed at advising how to form units in Lithuania, collected reports on the situation in the country. The Berlin activists prepared instructions and directives and through their intermediaries sent them to Lithuania. They discussed the possibilities of restoring Lithuanian statehood, specified the tasks of the insurrection at the outbreak of the war, etc. Of utmost significance for Lithuanian underground was the appeal 'Branguss vergaujantieji broliai' (Dear Enslaved Brothers), issued in March 1941. A score of copies of that appeal were found in Lithuania, mostly in Kaunas. The copies differ slightly from one another with regard to style and spelling. This testifies to their being recopied and multiplied in Lithuania. The appeal proclaims 'the approaching hour' of Lithuania's liberation, informs about the plans to form a new Lithuanian government and gives instructions about how to behave at the outbreak of the war: uprisings should start in large and small towns, and villages; control should be taken of prisons, bridges, factories and other objects of strategic importance. The population was urged to help the invading German forces in every possible way. ${ }^{1}$ In about three months the contents of the appeal turned into a strategic plan for the actions of the insurgents.

The idea of an uprising at the outbreak of the war between Germany and the USSR was propagated by the leadership of the LAF and by underground organizations in Lithuania. Although at the beginning their number was not great, and conspiracy considerations prevented closer ties between them, the number of secret groups increased at the approach of the war. The resistance movement was not centralized and there was neither a uniform programme nor leadership, nevertheless it grew into an uprising at the start of the war. The Sovietization of the country, arrests and deportations to Siberia left a deep imprint in people's memory and acted as the principal catalyst for the participation in the uprising.

The prevailing mood in Lithuania in 1940-41 was such that, according to the historian Vincas Trumpa, '... it would have been more difficult ... to hinder participation in the uprising than to instigate it, especially when the powerful Reich was just behind the border'.2

${ }^{1}$ LCVA, f. R-756, ap., 6, b. 560, 1. 3.

${ }^{2}$ V. Trumpa. K. Škirpos 'Sukilimą’ paskaičius. Akiračiai, no. 4, 1976. 
The uprising was interpreted likewise by the participants themselves. An account, prepared by the headquarters of one partisan unit in Dusetos, stated that the appearance of such units was caused by deportations in the early hours of June 14. Facing a very uncertain future, fearing arrests and deportation people began hiding in the forests in small groups of two - three men. The Dusetos account emphasizes: 'Not a single man can be found at home, especially at night. Weapons, concealed long ago, were again in demand.... ${ }^{3}$

\section{A Survey of Earlier Scholarship}

The process of demythologizing past events determines a more rational view of history and a more objective evaluation of events which is not conditioned by preconceived attitudes. So far this kind of stance is lacking, and three different points of view may be distinguished: the Soviet (class-oriented), the romantic and the critical (liberal).

The first trend is represented by works published in Soviet Lithuania. Its one-sidedness is determined by a biased selection of factual data and the application of ideological criteria in the choice of documents for publication. These works reflect the class orientation, political situation and the lack of personal and scholarly approach in their authors. In this paper they will not be dealt with.

The majority of émigré authors (in particular those residing in the USA) have chosen a romantic vision of the events under discussion. That was conditioned by several reasons: the events were recorded by witnesses and participants, unwilling to admit their own mistakes, the lack of critical approach was a kind of counterpoise to the class outlook, dominating in Lithuania, and the political up-to-dateness of the process influenced a certain schematism. "Political self-preservation' and a barricades mentality resulted in the mythologization of political events. The description was diversified only by the presentation and interpretation of different episodes of the resistance and uprising.

The romantic image dates back to the years of the war. The underground press presented the uprising as an outstanding historical event in the aftermath of which 'the nation's right to freedom was defended and won' and after the proclamation of

${ }^{3}$ Dusetų partizanų bürio veiklos kronika (parengta 19410804 ) (Chronicle of Dusetos partisan unit, prep. 4 Aug. 1941) LCVA, f. R-1106, ap. 2, b. 18, 1. 265. 
the Provisional Government, 'the functioning of Lithuanian sovereign government institutions, cut short by brutal force', ${ }^{4}$ was restored.

The uprising was dealt with especially frequently in the press of the Lithuanian Front - the Christian Democrat-biased underground organization. June 231941 was likened to February 161918 (when Lithuanian Independence was proclaimed) as regards its significance. The problems of the Provisional Government were widely discussed, too: its failure to maintain contacts with the provincial towns, the German prohibition to publicize its decrees and regulations; at the same time it was emphasized that it managed to organize 'state and local administration,' which the Nazis failed to re-organize into a committee or council, acceptable to them. One tendency manifested itself clearly: though the uprising and the Provisional Government were treated similarly by different political trends in the underground press, it is necessary to stress that particular attention, which the Christian Democrats paid to the date of the uprising and the six weeks of the functioning of the government.

Eventually several books devoted to the uprising were published. ${ }^{5}$ However, the abundance of articles and memoirs about the uprising led to the rise of some rather dubious tendencies - the appearance of a certain scheme in presenting the preparation for and the very process of the uprising: the leaders meet on 22 June and decide to start the uprising, in the morning of 23 June Radio Vilnius announces the restoration of independence and the formation of the Provisional Government, the first sporadic skirmishes take place (mainly in Kaunas, as a rule the units of the factories 'Metalas' and 'Drobe' are mentioned), the first partisan casualties are reported, the first session of the Provisional Government takes place on 24 June, the German forces come to Kaunas and find the city controlled by the partisans. True, the description of the events is made more varied by different interpretations of one or another episode of the uprising: opinions disagree as to who read the independence declaration on the radio, the circumstances of appointing

${ }^{4}$ I lietuvių tautą! Nepriklausoma Lietuva, 16 Feb. 1944: Džiaugsmo ir nusivilimo sukaktis. Nepriklausoma Lietuva, 21 June 1944.

5 Algirdas Budreckis. The Lithuanian national revolt of 1941. South Boston, 1968; K. Škirpa. Sukilimas Lietuvos suverenumui atstatyti: Dokumentine apžvalga. Vašingtonas, 1973; Pilypas Narutis. Tautos sukilimas 1941 Lietuvos nepriklausomybei atstatyti. D. 1, Oak Lawn, 1994, etc. 
Jurgis Bobelis to the post of the commandant of Kaunas are not clear, etc.

Based as it is on repeated statements and not being supported by indisputably authentic archival material the image of the June uprising among émigré authors is also unlikely to be definitive.

The number of casualties and participants in the uprising can serve as an example. The counting started as early as 1941. On 6 August the Lithuanian leader of the LAF, Leonas Prapuolenis, in his report to Commissar General Adrian von Renteln pointed out that 4,000 partisans lost their lives in the uprising (over 2,000 of them in Kaunas). ${ }^{6}$ The underground press did not doubt that number in the war years. Afterwards it was repeated by a number of the investigators and writers on resistance. Probably the first to arrive at a different conclusion (2,000 casualties) was General Stasys Raštikis. ${ }^{7}$ There were quite a few who did not doubt the accuracy of that figure. Meanwhile General Povilas Plechavičius indicated a figure of 6,000 victims. ${ }^{8}$

It is obvious that these data differ greatly. The methods of the count are not clear either. A natural question should arise: why was the number of victims increased? It is hard to give a definite answer to that question. There must have been several reasons: the data, presented by the contemporaries as well as by known politicians, the lack of documentary. evidence, political motives (an attempt to draw a direct interdependence between the scope of resistance and the casualty toll).

Similar doubts arise concerning the number of the participants of the uprising. Misunderstandings in this respect are by far smaller - the figures vary between 90,000 and 131,000. Most of the authors are unanimous - according to the press of the war years the uprising was 'the epic struggle of hundreds of thousands of partisans'. ${ }^{9}$

However, the discussion about the meaning of the uprising elicited the greatest response. A critical attitude was represented mostly by liberally-minded authors (futile action, selfish fight for posts, the insurrectionists did not free prisoners, they simply

${ }^{6}$ Generalkomisarui Dr. von Rentelnui igaliotinio L. Prapuolenio pasakyta kalba. Išlaisvintas panevéžietis. 16 Aug. 1941.

${ }^{7}$ S. Raštikis. Kovose dèl Lietuvos, d. 2, Vilnius, 1990, 293.

${ }^{8}$ P. Plechavičius. Lietuvos ginkluotosios pajègos 1939-1941. Kardas, no. $1,1990,13$.

${ }^{9}$ Džiaugsmo ir nusivilimo sukaktis. Nepriklausoma Lietuva, 21 June 1944. 
provoked the cruelties of the Red Army, etc.). The Christian Democrats also had quite a few criticisms (the uprising was merely a partisan movement, it had no political objectives and was based on illusions rather than on an analysis of the political situation). On the surface of things, one could trace echoes of some party squabbles in these arguments and ratings. A more careful analysis would show the discussion centring on different scales of priority values. In this respect Trumpa commented accurately that 'Freedom demands blood', but it 'cannot demand suicide ... Armed resistance, such as an uprising is meaningful only when there is a certain chance of winning. ${ }^{10}$

In the opinion of the majority, the uprising was a heroic deed. It showed the wide world the moral and spiritual values of the nation and its strong will and determination to restore the lost independence. Bronys Raila gave a fitting rebuff to the reproaches as to the illusoriness of the uprising: 'But for such mysteries our nation would have perished and disappeared long ago. It would have never awakened to a new life without miracles, mirages and illusions. Without all that it would never have reconstructed its independent state. On the whole, it would never have been re-born ... For our realism acknowledges that our enemies and neighbours will be much stronger than us for a long time to come'.11

The most controversial and sensitive issue is the policy of the LAF and the Provisional Government towards national minorities, and especially towards the Jews. Despite the fact that the Jewish fate had been sealed by the ideology of national socialism, the question is constantly raised about the extent of participation of the activists, insurrectionists and the government in the solution of 'the Jewish question' in Lithuania.

It is obvious that émigré authors, with rare exceptions, adhered to one model in presenting the events of 1940-41 in Lithuania. It lacked critical analysis. Many people believed that a nation needs a heroic, not a critical history.

The third - critical or liberal - trend would be illustrated only by separate recent publications both in Lithuania and abroad. The most outstanding émigré representative of this trend is Saulius Sužiedèlis. This author is known for his original standpoint and he does not avoid problematic controversial questions - the motives of the pro-German orientation of the

${ }^{10}$ V. Trumpa. K. Škirpos 'Sukilimą' paskaičius. Akiračiai, no. 4, 1976.

${ }^{11}$ B. Raila. Kitokios Lietuvos ilgesys. Vilnius, 1993, 343-44. 
LAF, the causes of anti-Semitism, the policy of the Provisional Government towards the Jews, the 'dark aspects' of the uprising - the acts of revenge and brutality at the outbreak of the war, etc. ${ }^{12}$ We presume that the author's attitude - his critical and analytical viewpoint as well as the comparative analysis of the events - is the most productive and perspective way to discuss the issues of the June uprising and resistance in general. The greatest danger in investigating such problems lies in mixing up together history and ideology. When ideologists create myths, history itself or at least some of the recent events are liable to turn into myths.

\section{The Uprising in Kaunas and Vilnius}

Preparations for the uprising began as early as 1940. Plans were drawn up by the Berlin headquarters of the LAF. The beginning of the uprising coincided with the outbreak of the war, and there is nothing surprising in this. As Raila rightly remarked, 'from the very restoration of independence a sober-minded politician and a soldier had to learn to plan their strategy in accordance with the existing ratio of forces' ${ }^{13}$

Kaunas came to be the centre of the uprising. Already in the evening of 22 June the radio station of the city was occupied by the insurgents, its defence was organized and radio broadcasts were about to start. It was from here that in the morning of 23 June L. Prapuolenis read out the declaration about the restoration of Lithuania's statehood and announced the members of the Provisional Government.

Command of the partisan activity was directed by the spontaneously formed Local Safeguard Headquarters. Partisan units were organized, premises and headquarters safeguard groups established, and recruitment, personnel, operations, armament and other structures were set up. Kaunas and its suburbs were divided into ten sectors. According to the chief of the medical service, V. Labokas, the first-aid groups were sent to the units already in the evening of 23 June. About 40 medics (ca. 20 of them doctors) were sent to partisan units in the course of June 23-36. The lightly wounded were attended to by medics on

${ }^{12}$ S. Sužiedẻlis. Penkiasdešimčiai metų praejjus: lietuvių tautos sukilimo ir laikinosios vyriausybès istorijos interpretacijų disonansai. Metmenys, no. 61, 1991, 149-169; 1941 metų sukilimo baltosios dèmès (pokalbis su S. Sužiedèliu) Akiračiai, no. 9-10, 1991, no. 1, 1992.

${ }^{13}$ B. Raila. Kitokios Lietuvos ilgesys, p. 334. 
the spot, and those who received serious injuries were sent to the hospitals. ${ }^{14}$

The property protection department 'stationed 30 guard groups and armed guards in 15 places ...' Two partisans were killed and two were wounded while performing their task'. ${ }^{15}$ Between June 24 and 27 partisan groups patrolled the city streets, kept guard over the former customs store-houses and factories. Guard duties were given up after June 27 to be taken gradually over by the watchmen. The partisans, after 'getting certificates of their participation in the uprising ... started returning their weapons and getting to their previous jobs'. ${ }^{16}$ The Local Safeguard Headquarters functioned until the Provisional Government established its own organs and appointed their officials. It must be stressed that commanding the partisan units was very complicated: the location of the headquarters was often changed and the rebels did not know its address, and to contact them was also next to impossible since they had no permanent headquarters and no telephones. Neither were there any contacts with the LAF and the Provisional Government.

The tasks of individual units were very much alike. According to a member of the uprising and the Provisional Government, Kazys Ambrozaitis, his group was 'to protect the stores and any other property from being looted, to protect against the assaults of soldiers, to prevent bridges being blown up, to attempt to free prisoners,... However, getting weapons was of primary importance'. Their unit was given the task of taking over the first police station. That was not hard, since the premises were already empty. The men barricaded themselves in, and the place became the partisan headquarters of the Old Town of Kaunas..$^{17}$ The reminiscences of another eyewitness, P. Mačiulis, are similar: 'Disarming separate smaller groups of soldiers, our partisans procured weapons in the first place, plundered a small Bolshevik storeroom in Parodos Square..., blocked the road against the Red Army, attempting to cross the

${ }^{14}$ Kovų su bolševikais aukos Kaune. Savitarpinès pagalbos žinios. 13 June 1942.

${ }^{15}$ The report of 28 June 1941 to the Commandant of Kaunas. LCVA, f. R-1444, ap. 1, b. 9, 1. 44.

${ }^{16}$ The reports of 24-27 June 1941 to the Commandant of Kaunas, Chief of the Military Protection and the Chief of the Property Protection. LCVA, f. R-1444, ap. 1, b. 9, 1. 21-22, 42-43.

${ }^{17}$ K. Ambrozaitis. Aukos ir vilties dienos. I laisvę, no. 10, 1956, 28-29. 
Nemunas at Panemune, and in the first days the partisans themselves lost nineteen lives'. ${ }^{18}$

Most of the stubborn battles took place in Šančiai, a suburb of Kaunas. Large units, consisting of 200 to 300 men, were formed in the factories "Metalas' and 'Drobè'. 'Metalas' was situated in the centre of the suburb close to Juozapavičius Ave., along which the Red Army was retreating from Kaunas in the direction of Jonava, and skirmishes between the men of that unit and the retreating soldiers were frequent.

People spontaneously joined the resistance units, young men not rarely were led by the desire of adventures as well. The formation of the LAF headquarters with its political, military, propaganda and press and supply departments was taking place also in the first days of the war.

Summing up, it can be said that spontaneity was characteristic of partisan action in Kaunas on June 23-25. The majority of the incidents were carried out by small groups, which as a rule, formed sporadically. The enthusiasm of the insurgents, however, could not make up for the lack of weapons and experience.

The extent of the uprising in Vilnius was much smaller. The main cause was the ethnic composition of the city's inhabitants: Lithuanians there were a minority. The disclosure of the leading underground group in Vilnius, led by Major Bulvičius, and the arrests of its members played no small role, either. It was just this organization that drew up the principal plans of resistance to the Red Army.

Notwithstanding all that, the actions in Vilnius started in the evening of 23 June: the post office was the first to be taken by the partisans. On the same day the headquarters of the partisan students were set up in the central building of the University of Vilnius and a Lithuanian flag was hoisted on a turret there. In the morning of 24 June guards were stationed in the freight station, aviation storehouses, i.e., in places, where 'looting and sabotage could be expected'. ${ }^{19}$ The radio station was occupied by a partisan unit on 24 June. The tricolours were already fluttering on the tower of the Gediminas Castle and elsewhere in the city, when German motorized units appeared in the streets. ${ }^{20}$

${ }^{18}$ P. Mačiulis. Kritiškos pastabos dèl K. Škirpos knygos 'Sukilimas'. Tèvynès sargas, no. 2, 1976, 86.

${ }^{19}$ Pasikalbejjimas su buvusiu Vilniaus miesto apsaugos būrio vadu A. Valeška. Naujoji Lietuva, 3 July 1941.

${ }^{20}$ Pirmoji trispalvè Gedimino kalne. Naujoji Lietuva, 3 July 1941. 
In Vilnius, as well as in other stationing places of the 29th territorial riflemen corps, the insurrectionists were joined by Lithuanian fighters. About 7,000 - 8,000 Lithuanians served in that corps. At the outbreak of the war the majority of them had deserted the Red Army and some of them started to regroup in Vilnius on 24 June. The Provisional Government planned to organize national forces to take care of the country's safety. Unfortunately, these plans were not fated to materialize. It could be said preliminarily that in the middle of July the military commandant of Vilnius Col. Zehnpfennig informed the Lithuanian army headquarters that he was taking over all Lithuanian units and gave an order to form three battalions, each of 800 men. These battalions were to be called the Vilnius Reconstruction Service. But that order was not carried out as it was followed by another one: to form one battalion to safeguard the city of Grodno. ${ }^{21}$ At the same time the reconstruction battalions were disbanded, and all Lithuanian battalions were named Lithuanian self-defence units.

\section{Resistance in the Provinces}

The uprising rapidly spread through the whole of Lithuania. On hearing the national anthem on the radio and information about the establishment of the Provisional Government, people began organizing partisan detachments, hoisting national flags, occupying the premises of the former local authorities (usually deserted by that time), obtaining weapons and disarming retreating Soviet soldiers. Archival documents testify to the formation of most partisan units at the start of the war. People, who previously had been unaware of the underground and the activist front, joined the resistance. The partisans, acting in Krekenava, county of Ukmerge, presented themselves to the Germans to clarify their status. When asked if they were members of the activist organization, they answered that they did not know of any such organization. They only admitted to being simply 'partisans'. ${ }^{22}$

To help understand the course of events in the provinces, we will present a detailed description of the events in Pušalotas, county of Panevežys. Tricolour flags are hoisted in the morning of 23 June on hearing the Lithuanian national anthem, presently the post office and the railway station are taken over. Lieutenant

${ }^{21}$ B.R.V. Lietuvos Apsaugos Dalys. Karys, no. 9, 1958, 296.

${ }^{22}$ Masinès žudynès Lietuvoje, d. 1, Vilnius, 1965, 57-58. 
Vladas Šimoliūnas starts organizing a partisan unit. In the evening of the same day the partisans capture three armed militiamen and four Communists on the arrival of a train from Panevéžys. Thus, more weapons are obtained. On 24 June already about 20 militiamen arrive from Panevezžys. They are met by 15 armed and 10 unarmed partisans. The baptism of fire takes place. On 25 June two partisans are killed in the encounter. The Germans arrive at Pušalotas on 26 June. People meet them 'with flowers and with tears of joy in their eyes'. ${ }^{23}$

This brief review of the events in a small Lithuanian town is rather typical, accurately reflecting similar events in other parts of the country.

It goes without saying that the partisan activity varied in different localities. There were scores of places in which it is either not mentioned at all or reported as having started only after the arrival of the German troops. According to Algirdas Julius Greimas 'there was no uprising whatsoever' in the industrial city of Šiauliai. The author writes: 'The next morning [right after the German army had occupied the city ] on hearing that the "partisans" were gathering at the Girls' Teacher Training Seminary, I hastened there, too. People kept coming in great numbers. As a reserve officer, I soon turned into a platoon commander and took to various activities (e.g., with the Seminary seal I granted a permission for the former director to open the bakery, so that the city might have bread, etc.). In the afternoon the number of those arriving increased again, and I was appointed commander of a company (about 200 men). Of course, the men were not armed'. ${ }^{24}$ The homeguard service, consisting of partisans, started functioning only on 27 June.

Regardless of the unequal activeness of the partisans the resistance was gaining momentum. The scale of the movement was especially large in the city and county of Kaunas, in the counties of Švenčionys, Mažeikiai, Panevežys and in the town and county of Utena.

Partisan tactics varied from locality to locality and depended largely on circumstances. In general, spontaneity was typical of the organization of the units and their battles. Another peculiarity (and a great problem) was the shortage of weapons. Suffice it to say, even the Lithuanians, serving in the Lithuanian

2.3 A.D. kovų aprašymai (Battle descriptions by A.D.). LMAB RS, f. $222-1756,1.3-5$.

${ }^{24}$ A. J. Greimas. Apie 1941 metus Lietuvoje. Akiračiai, no. 6, 1992. 
detachments of the Red Army, complained of the shortage of ammunition, let alone the partisans. The master sergeant of the 184th division Kazys Leknickas writes in his memoirs: 'It was nothing but ridiculous - the war had just broken out, and we were given five cartridges each and dry rations for one day'. 25

The resistance movement may be rightly regarded as the uprising of the youth. That is acknowledged by the participants themselves and supported by the analysis of the partisans' age. Out of 22 partisan units in the Utena county the 'youngest' was the detachment of the village of Kimenai: the average age of the men was 24.3 years, while the 'oldest' was that of the village of Andrioniškis - the average age - 34.8 years. ${ }^{26}$

A mood of elation prevails in most of the descriptions of the appearance of German troops - women bringing eggs and sausage and giving milk to the soldiers to drink, girls presenting them with flowers, etc. The press then wrote: 'It is a marvellous act and sight when both the German soldiers and their weapons are decorated with flowers, the soldiers are fed while in their turn they treat the children to sweets and the adults to cigarettes. Lithuanian citizens! Go ahead helping the German troops in every possible way so that our forests and bushes might be immediately cleansed of Jews, Bolsheviks and other alien dregs of our society and of Lithuanian traitors'. ${ }^{27}$ That is why the German army Commander of Vilnius von Ostman rightly stated in his order of 26 June: 'The German Army is met by Lithuanian citizens as their liberator and expects adequate reaction towards themselves on the part of the soldiers'. ${ }^{2}$

The belief that the Germans had brought independence to Lithuania did not subside throughout July and August. Thus, at the meeting convened in Vainutas (county of Taurage) on 27 July, gratitude to the German army was expressed, Hitler was saluted, and at the same time a resolution was adopted congratulating the Provisional Government and Lithuania's

${ }^{25}$ K. Leknickas. Nuo tarnybos pulke iki Savisaugos dalinių. Karys, no. 8, 1979, 317-318.

${ }^{26}$ Utenos apskrities partizanų sąrašai (Lists of the Utena county partisans). LCVA, f. R-1652, ap. 1, b. 1, 1. 1-6.

${ }^{27}$ Lietuvos taurieji piliečiai ir pilietés ... Išlaisvintas panevežzietis, 4 July 1941.

28 Vilniaus miesto karo vado įsakymas (Order of the Commander of Vilnius). LCVA, f. R-689, ap. 1, b. 1, 1. 3. 
independence. ${ }^{29}$ Even on 10 August, i.e., after the dissolution of the Provisional Lithuanian Government, the participants of a mass meeting in Rietavas (county of Telšiai) congratulated the 'Great Leader' of Germany on the occasion of returning Lithuania back to 'the civilized family of nations' and accepted the following decision:

'I. To request and require the Government to lead the Nation and the State to complete independence, incorporating into the State all the historically ethnographic regions.

II. To ask the Government to establish adequate diplomatic relations with the Great Germany, as befits a sovereign nation and state.

III. To oblige the Government to carry out without delay a national land reform in keeping with the people's aspirations' ${ }^{30}$

Only in the course of time the attitude towards the Germans was going to change: two years later the underground press wrote that the Germans 'can only be seen off with flowers'. ${ }^{31}$ However, during the first week of the war and for some time afterwards the confidence in them and 'the psychology of flower throwing' were fully comprehensible.

The uprising of Kaunas lasted until 25 June, and in the outlying districts the resistance to the retreating Red Army continued approximately through the first week of the war, with the German troops marching to the East.

Formation of Central and Local Organs of Government and their Functioning

The projects of forming the Provisional Government had been prepared by the LAF headquarters in Berlin. It was there on the first day of the war between Germany and the USSR that the government, led by Kazys Škirpa, was set up and its composition announced. This government, however, was not fated to perform its duties: in the morning of 23 June the insurrectionist government was made up in Kaunas. Since Škirpa was prohibited to leave Berlin, the duties of the government leader fell to Juozas Ambrazevičius.

${ }^{29}$ Vainuto nuovados viršininko 19410728 raportas Tauragès apskrities policijos vadui (Report of Vainutas police chief of 28 July 1941 to the police chief of Taurage county). LCVA, f. R-1476, ap. 1, b. 3, 1. 61.

${ }^{30}$ Susirinkimo protokolas (Minutes of the meeting). LVOA, f. 3377, ap. 55 , b. $50,1.260-61$.

${ }^{31}$ Dvejos skaudžios metinès. Nepriklausoma Lietuva, 15 June 1943. 
The very next day (24 June) the first government session was held and the country's defence council was established. There were several reasons for taking no time in forming the government. They were precisely defined by Ambrazevičius himself: 'The first task of the Provisional Government was to confront [the Germans] with a fait accompli - Lithuania is independent, it has restored order in its institutions and enterprises ... The second ... to release the country from the traces of the Soviet regime' and the third ...'to make a display of their social face'. ${ }^{32}$

The coalition government, the majority of which consisted of Christian Democrats, made its existence known in the first issue of the periodical I laisvę (Towards freedom) on 24 June (the title of the newspaper was chosen quite symbolically, implying that full freedom had not yet been achieved):

'A newly formed provisional government of reborn Lithuania hereby declares the restoration of a Free and Independent State of Lithuania.

In the face of the clear conscience of the whole world the young Lithuanian Government wholeheartedly pledges to contribute to the organization of Europe along new principles.

Tortured by the cruelties of the Bolshevik terror, the Lithuanian Nation is determined to build its future along the lines of unity and social justice' ${ }^{33}$

The LAF staff, too, declared that the established Provisional Government 'is taking over the helm of the state and assuming the control of its institutions.' L. Prapuolenis thanked the German nation for rescuing European culture and civilization, urging the population to help the German army, and never doubting the declaration that a free and independent Lithuania was being restored..$^{34}$

Maintaining the former status quo, the government tried to manoeuvre: to restore historical justice by returning the private ownership as well as carrying on an effective and socially oriented policy. The laws and decrees, adopted by the Provisional Government, were based on two more principles: anti-Semitism and anti-Sovietism. All the de-nationalization laws, as a rule, were not to be applied to the Jews, to the non-citizens of Lithuania and to persons, "who had been active against the interests of the

${ }^{32}$ J. Brazaitis. Vienu vieni. Vilnius, 1990, 77-80.

${ }^{33}$ Atstatoma laisva Lietuva. I laisvę, 24 June 1941.

${ }^{34}$ L. Prapuolenis. Viskas Lietuvai. I laisvę. 24 June 1941. 
Lithuanian nation' (this wording, used in the articles of the laws, had never been explained). ${ }^{35}$

In a very short time the Provisional Government restored the former administrative structures, which had existed in the country prior to 15 June 1940 - the local administration of the counties, districts and towns; a hundred diverse laws, decrees and regulations were passed. This activity, however, was greatly obstructed by the Nazi military and later by their civilian administration.

As the Red Army retreated, Vilnius and Kaunas found themselves in the zones of the military operations of different German troops. Thus, in Vilnius the City and Region Committee (hereafter Committee) was established on the initiative of the activists and insurrectionists to deal with the problems of the civilians and to establish contacts with the German military authorities. A lecturer of the University of Vilnius Stasys Žakevičius was elected its chairman, and administrators were appointed only temporarily because there were no authorizations from the Provisional Government in Kaunas. The publication of the newspaper Naujoji Lietuva (New Lithuania) was also started. The title, again, was not accidental. In the words of its editor, Rapolas Mackonis, 'the title of the paper sought to symbolize both the new epoch and the links of Vilnius to Lithuania'. ${ }^{36}$

On June 24 Žakevičius and the military commander of Vilnius, von Ostman, signed an order, introducing martial law from 25 June. Eventually, the collaboration between the German military authorities and the Committee in adopting orders and regulations was also declared. ${ }^{37}$ The military authorities cooperated with the Committee closely, yet the latter's functions were strictly limited. Not once were the boundaries of the Committee's competence pointed out to Žakevičius in the official letters of the military authorities: 'Problems, such as food, maintenance, means of transportation, housing, regulation of prices and wages, etc., are numerous; coping with them expertly and professionally, you are sure to render service to the population and earn confidence of the

${ }^{35}$ Cf., e.g.., Miestų ir žemès sklypų denacionalizacijos ịstatymas (Law on de-nationalization of land plots in towns and coutryside). LCVA, f. R-496, ap. 1, b. $4,1.9$.

${ }^{36}$ R. Mackonio dienoraštis. Sąsiuvinis Nr. 1. 1941 (R. Mackonis' diary. Fascicle no. 1. 1941). LYA, Baudžiamoji byla Nr. 203117/3, 1. 21-22.

${ }^{37}$ Issakymas Nr. 1. Naujoji Lietuva. 29 June 1941. 
German administrative organs at the same time. Other matters are as yet irrelevant'..$^{38}$

There were joint conferences of the Committee and the representatives of the German Military Command. Various everyday questions were usually discussed: organization of public works, health care and food catering, finances, judicial problems, etc. The members of the Committee were present at the discussions of everyday economic and social problems of the city and the region, but they were excluded from the solution of political issues. Already during the first week of the war all the members of this institution had to sign a pledge "to wholeheartedly help the German nation in its struggle with the mortal enemy of Europe - Bolshevism', to promise never to raise any political issues during the war years, never to accept and carry out any instructions without their prior co-ordination with 'the corresponding institutions of-the German army.' The pledge stated that 'the main principle in performing one's duties was to comply with the needs of the Germans, in order to ensure the final victory in the East' ${ }^{39}$

The work of the Committee was aggravated by poor connections with the Provisional Government. That was stressed by Ambrazevičius himself: 'Particularly numerous were the obstacles in the relations between the Government and Vilnius and its region. Being in another military zone and getting clearcut instructions of the military commandant of Vilnius to ignore the orders of the Provisional Lithuanian Government residing in Kaunas, the Provisional Committee of Vilnius could not establish close contacts with the Government'. ${ }^{40}$ The situation took a different turn at the end of July after the introduction of civilian rule - the division of the country into two different parts was done away with. However, at that time the Provisional Government was living its last days.

During the uprising the local authorities were restored in the counties and rural districts. In compliance with the governmental decision all the former officials of the Republic of Lithuania had to take their old working places and 'to perform

${ }^{38}$ Karinès administracijos skyriaus viršininko 19410703 raštas S. Žakevičiui (Note of the department chief of military administration of 3 July 1941 to S. Žakevičius). LCVA, f. R-643, ap. 3, b. 14, 1. 102.

${ }^{39}$ Pasižadejimas (The pledge). LMAB RS, f. 165-167, 1. 2.

${ }^{40} \mathrm{~J}$. Ambrazevičiaus kalba 19410805 Kaune (J. Ambrazevičius' speech of 5 Aug. 1941 in Kaunas). LVOA, f. 3377, ap. 58, b. 265, 1. 4. 
their previous duties.' Without waiting for any directions, the former employees and insurrectionists took to setting various committees, established institutions of local authorities and organized the police. Institutions, springing up spontaneously de facto, eventually came to be legalized de jure, often without being changed in any way. Thus, during the period of the Provisional Government and the LAF, the activists and partisans had their share in the reconstruction of the independence of Lithuania. Local initiative was absolutely necessary and indispensable at a time when the Government was limited in its capacity to influence the processes in the provinces.

Unfortunately, insufficient control of the processes on the part of the Government and the overlapping of the functions of local authorities created conditions for arbitrary rule during the uprising and the subsequent period.

Elimination of the Provisional Government, the Committee and the LAF.

Having occupied Kaunas and found the Provisional Government already formed, the Germans immediately tried to clarify what attitude ought to be taken toward that situation. Since the Government had been formed without Germany's backing, giving it any support was to be avoided. The directions, issued to the German army on 26 June, speak for themselves: 'The proclamation of Skirpa's government occurred without the support of German official authorities. Therefore, any support to that government is to be avoided. Military authorities must abstain from any interference with decisions which are within the exclusive competence of the political leadership'. ${ }^{41}$

That attitude did not change later, either. On arriving in Kaunas on 11 July, the official of the German ministry of foreign affairs P. B. Kleist merely confirmed the previous viewpoint - he informed Ambrazevičius that "the Provisional Government cannot be tolerated. It must be re-organized into some committee or council within the framework of the German administration.' The advise of Colonel Škirpa, residing in Berlin, was 'not to expect anything positive'. ${ }^{42}$

A question may arise why the Provisional Government was not abolished in the first or second week of the war. The

${ }^{41}$ Bronis. J. Kaslas. The USSR-German Aggression Against Lithuania . New York, N.Y., 1973, 352.

${ }^{42}$ J. Brazaitis. Vienu vieni, p. 87. 
explanations were varied. Škirpa attempted to attribute the merits to himself. A comparatively long existence of the Government and a lengthy period of its activity were accounted for by some sympathy of the Nazi military authorities to the idea of Lithuania's autonomy. It was deemed that General Pohl's Austrian descent had allegedly contributed to a rather tolerant estimation of Lithuanian power in as much as it did not interfere with the German institutions and policy. An opinion was also voiced that the members of the Government had not been arrested only due to the opposition of the German military commander in Kaunas General Karl von Roques.

The fate of the Provisional Government was determined after the introduction of the German civilian rule in Lithuania. We would presume that the military authorities did not resort to drastic measures against the Government not because the idea of autonomy appealed to them, but rather due to the delimitation of the spheres of influence. Lithuanian administration through Lithuanian institutions was beneficial to military authorities, since the army was not going to take over those functions which are, by their very nature, alien to it. The military authorities, however, controlled the activities of the Provisional Government, constantly declaring the superiority of the German laws, and that completely sufficed in the transitional period. On the other hand, the decisions, taken by the Lithuanian Government, were practically invalid. The denationalization laws were of a rather declarative character and the retention of the status quo, of Soviet laws and order amply satisfied the military rule.

The transitional period came to an end in the second half of July: in his appeal to the Lithuanians on 28 July, Heinrich Lohse pointed out that Adolf Hitler by his decree of 17 July appointed him Reich Commissar for the region of the East (Reichskomissar für das Ostland). Dr. Adrian von Renteln was appointed Generalkomissar for Lithuania. That appeal also contained an indication that the occupational authorities were going to request the services of the trustees from the Lithuanians. ${ }^{43}$

That time was fatefully approaching. The press did not delay to publicize the fact that von Renteln 'received Lithuanian public figures' ${ }^{44}$ At that reception the Generalkomissar declared

${ }^{43}$ Atsišaukimas. Lietuviai! I laisvę, 19410730.

${ }^{44}$ Generalinis Komisaras Dr. von Renteln prièmé lietuvių veikèjus. Ūkininko patarejas, 19410815. 
that the activity of the Provisional Government was suspended: 'After the introduction of civilian rule, your functions in the capacity of ministers are checked. Finally, your country's status will be settled by the Führer when the war is over. Therefore, you are appointed Counsellors of the Generalkomissar as my trustees and advisers' ${ }^{45}$ Gen. Petras Kubiliūnas was appointed First General Counsellor.

There was nothing the Government could do but cut short its activities. Its last sitting took place on 5 August. Although the government ceased functioning, it did not give up the idea of restoring Lithuania's independence. The majority of the ministers resigned, refusing to accept the posts of general counsellors. The ministries were closed down. On 13 August von Renteln signed an order, finally dissolving the Provisional Government: 'Having taken over Lithuania's civilian administration I regard the functioning of the Provisional Government as terminated and from August 5 I relieve the members of the Provisional Government of their posts ... The dismissed ministers are entitled to compensation, equalling their monthly salary'. ${ }^{46}$

Of all the Baltic republics Lithuania was the only in which a government was established. True, some authors write about an uprising in Riga and the formation of Latvian government bodies, about the city of Tartu's being under the control of the local administration between 10 and 28 July, yet these analogies are not quite adequate. Of all the former republics of the USSR, possibly only Ukraine could be singled out, where the meeting of the representatives of Western Ukraine was convened in Lvov on 30 June with the aim of declaring the independence of Ukraine and forming the government under the leadership of Stepan Bandera. The organizers, however, were dispersed, and Bandera and his deputy were taken to Germany.

The Committee of the City and Region of Vilnius existed longer for several reasons. The Committee, unlike the Government, did not lay claims to political power and did not rush to revoke laws and other legal acts, passed by the Soviets; the enterprises, the owners and holders of nationalized houses and plots of land were obliged to pay taxes according to the

${ }^{45}$ Kalba, pasakyta Generalinio komisaro Generaliniams tarejams Kaune 19410805 (Generalkomissar's speech to General counsellors in Kaunas, 5 Aug. 1941). LCVA, f. R-685, ap. 4, b. 2, 1.1

${ }^{46}$ Lietuvos Generalinio Komisaro 19410813 įsakymas (Aug. 131941 order of Generalkomissar for Lithuania). LCVA, f. R-617, ap. 1, b. 18, 1. 1. 
formerly established order; no changes were made in the rural economy. This was convenient for both the German military and the civilian authorities - no reforms were planned; it was necessary only to secure stability in the occupied regions. On the other hand, the Committee could not function long, since after the introduction of civilian rule administrative functions were passed on to the First General Counsellor and to the functionaries, appointed by him. Correspondingly, the activities of the Committee were checked by the Commissar General's order of 15 September 1941. The Commissar of Vilnius expressed his gratitude to the members of the Committee for their work. ${ }^{47}$ Gradually the employees of the Committee were relieved of their duties.

The process of disarming and dissolving or reforming the partisan and activist units (practically the armed units of the Provisional Government) was carried on. In the city and county of Kaunas that operation began on 28 June by reorganizing those units into regular detachments. Practically the dissolution of the partisan units and their re-organization into squads of Auxiliary Police was a much longer process, and not only in the provinces.

When the Provisional Government was dissolved and the partisan units were disbanded, reformed and taken under the guidance of the Nazis, the LAF felt it its duty to come out against the German civilian power. The most striking example of that move was the memorandum of 15 September 'On the Status of Lithuania after the Introduction of German Civilian Rule.' In this document the LAF was presented as a military organization, whose aim was to restore independent Lithuania by means of an armed uprising. The text of the memorandum 'To the Leader of the Great Germany Adolf Hitler and his Invincible Army' further deals with the LAF's concern over such issues as the dissolution of the Provisional Government, the restoration of 'the principles of the Bolshevik order' (non-denationalization of private property, etc.), the restriction of the functioning of higher schools, the prohibition of the national anthem and the removal of the national flag from Gediminas Hill in Vilnius, etc. Therefore, the leaders of the LAF resolved 'to draw the attention of the High Command to the fact that those abnormalities of life in Lithuania could disappear, if the further existence of the Lithuanian state

${ }^{47}$ Vilniaus miesto komisaro 19411002 padèka Komitetui už darbą (Letter of gratitude of the Commissar of Vilnius to the Committee, October 2 1941) LCVA, f. R-614, ap. 1, b. 287, 1. 1. 56. 
were acknowledged and the country were led by its own government.' The memorandum was signed by Leonas Prapuolenis, Gen. Stasys Pundzevičius, Col. Mykolas Mačiokas, former ministers of the Provisional Government Juozas Ambrazevičius, Adolfas Damušis, Kazys Vencius among others - by thirty persons in all. ${ }^{48}$

The response to the memorandum did not take long. By the Commissar General's order of 26 September the Lithuanian Activist Front was closed down and its property confiscated. ${ }^{49}$ The only organization left to function openly was the pro-Nazi Lithuanian Nationalist Party.

\section{Factual Aspects of the Uprising}

The fighting activity of the partisan units is indirectly characterized by the numbers of victims and participants of the uprising. Already in 1941 the estimation of the number of partisan victims and the collection of the material relating to their battles, were undertaken. This was the concern of local authorities as well as of the Provisional Government. On 7 July the Minister of Internal Affairs Jonas Šlepetys issued a circular to county and town authorities, to the mayors and boards of the cities and towns, urging them to gather information about 'the deportations of the people, the outbreak of the war and the partisan activities'.$^{50}$

Lists were compiled of the members of resistance units, and relief was organized for the victims and their relatives. As early as the first week of the war the 'Partisan Bureau was set up, the 'Red Terror' Museum collected rich material about the participants of the uprising and the casualties. The analysis of the material reveals the following figures: 161 killed in Kaunas, 24 in Vilnius and ca. 460 in the provinces. The total number came up to ca. 650 .

These data could be made more precise. There were several causes of possible errors in the calculation. The concept of " $a$ partisan' was not quite clear - its definition was formulated only in 1942; mistakes occurred easily in the compilation of the lists; cases when a casualty was named 'a partisan' in one list and 'a civilian' in another were not infrequent. The appearance of some

${ }^{48}$ LCVA, f. R-739, ap. 1, l. 1-9.

${ }^{49}$ Generalkomisaro Kaune parèdymas. Tèvyne, 19411003.

${ }^{50}$ Apskričių ir miestų viršininkams, apskričių valdyboms ir miestų burmistrams (To the chiefs of counties and towns, heads of the county boards and mayors. LCVA, f. R-1099, ap. 1, b. 8, I. 4. 
inaccurate data might also be attributed to material incentives. The Provisional Government had passed a resolution that the time served as a partisan should be paid for, whereas whether one could be called 'a partisan' or not depended on the commander of the unit - he issued a certificate, indicating in what unit and for how long the partisan had served. ${ }^{51}$ It should also be borne in mind that partisans, who fell in the battles with the Red Army, were sometimes coupled with those killed by the Germans - the fact, however, mostly passed over in silence in the descriptions of the events. One of the leaders of the Lithuanian Nationalist Party, its secretary general Zenonas Blynas, wrote in his diary that in Suvalkija (southern Lithuania) the first German troops shot quite a few Lithuanian partisans, since allegedly they did not speak German and were unable to explain themselves. ${ }^{52}$ Taking into account all these considerations, it could be said that the total number of casualties did not come up to 600 .

Similar intricacies emerge, too, in trying to ascertain the number of the participants of the uprising. The most numerous were the insurrection fighters in Kaunas and its suburbs - there were nearly 4.000 of them. In the whole of Lithuania there were ca. 400 partisan units. Knowing the average number of men in the unit (40-50), it is possible to establish the total number of the partisans - about 16.000-20.000 altogether..$^{53}$ These figures, however, may be increased because in establishing the size of the units mostly that archival material was used which reflected the situation in the regions where most stubborn fighting had taken place; some data deal with the state of affairs in July, when the number of the men increased, compared to the first days of the war.

\section{Concluding Remarks}

The period of Lithuania's independence in the two inter-war decades had formed national consciousness. Therefore, loss of statehood could not but arouse opposition. The uprising against the retreating Red Army represented the climax of anti-Soviet resistance which had started in the autumn of 1940.

${ }^{51}$ V. Brandišauskas. Siekiai atkurti Lietuvos valstybingumą (1940 06 1941 09. Vilnius, 1996, 85-86.

${ }^{52}$ Z. Blyno dienoraštis (Z. Blynas' diary). LVOA, f. 3377, ap. 55, b. 39, 1. 104.

${ }^{53}$ In greater detail see V. Brandišauskas. Siekiai atkurti Lietuvos valstybinguma (1940 06 - 1941 09), p. 15-16, 82-88. 
The uprising was directed against the retreating Red Army and against German interests, since it aimed at the restoration of Lithuanian independence and the establishment of the Provisional Government. There were great aspirations to take over Lithuania's administration and set up the organs of local authorities prior to the new occupation.

Though the declaration of the Provisional Government about the restoration of Independent Lithuania turned out to be more declaratory, and the aims of the partisans too illusory, evaluations of the uprising in Lithuania will all the time be more psychological and existential rather than logical and based on advantage and success. This evaluation cannot be dissociated from the individual's right to make a choice, and choice in every particular case has always been a way of making oneself meaningful in the life of the nation. 